\title{
Soil Ecology and Bioaccumulation of Heavy Metals by Calotropis procera (Ait) in Drylands of South Eastern Kenya
}

\author{
Festus Mbatha Mutiso ${ }^{1 *}$, Jacinta Kimiti ${ }^{1}$, Alice Muchugi ${ }^{2}$ and Josphert Kimatu ${ }^{1}$ \\ ${ }^{1}$ South Eastern Kenya University, School of Environment, Water and Natural Resources \\ Management, P.O.Box 170-90200, Kitui, Kenya \\ ${ }^{2}$ International Centre for Research in Agroforestry (ICRAF), P.O. Box 30677-00100, \\ Nairobi, Kenya \\ *Corresponding author
}

\begin{tabular}{|l|}
\hline K e y w o r d s \\
$\begin{array}{l}\text { Calotropis procera, } \\
\text { Heavy metals, } \\
\text { Bioaccumulation, } \\
\text { Phytoremediation, } \\
\text { Phytoextraction }\end{array}$ \\
\hline Article Info \\
$\begin{array}{l}\text { Accepted: } \\
\text { 20 June } 2021 \\
\text { Available Online: } \\
\text { 10 July } 2021\end{array}$ \\
\hline
\end{tabular}

\section{A B S T R A C T}

Calotropis procera is a wild species that is drought-resistant and plays a number of economic and ecological uses. The species is important in soil fertility improvement, pollution control by monitoring sulphur dioxide emissions in the air and suitable indicator of exhausted soil. This study was undertaken in drylands of South Eastern Kenyato evaluate the species' soil ecology and ability to bioaccumulate heavy metalsThe objectives of the research were to determine the soil chemical and physical properties for survival of $C$. procera and to determine the ability of $C$. procera in phytoextraction of heavy metals from the soil. To understand the soil chemical and physical properties for growth of $C$. procera, two sites namely a farmland and a natural stand of $C$. procera were used. In the two sites, soil samples were collected and analysed for soil $\mathrm{pH}$, total $\mathrm{N}, \mathrm{P}, \mathrm{K}$ and bulk density. C. procera tissues (leaves) were harvested and analyzed for total N, P, K, OC, Zn, $\mathrm{Mn}, \mathrm{Cu}$ and $\mathrm{Fe}$. One-way ANOVA was applied to assess the significance of variations in the soil chemical properties ( $\mathrm{pH}$, total $\mathrm{N}, \mathrm{P}$ and $\mathrm{K}$ ), Plant tissue data (total $\mathrm{N}, \mathrm{P}, \mathrm{K}, \mathrm{OC}, \mathrm{Zn}$, $\mathrm{Cu}$ and $\mathrm{Fe}), C$. procera provenances and spacing variables in relation to the field plots. Pearson simple linear correlation coefficient (r) was calculated for assessing the type of relationship between the study site and the natural stand of $C$. procera in relation to the soil chemical properties. There were no significant differences in subplots soil chemical properties. Correlation analysis showed a strong positive spatial relationship (Pearson, $\left.\mathrm{P}<0.01, \mathrm{r}_{\mathrm{s}}=0.734\right)$ in soil chemical properties between the artificial and the natural stand of $C$. procera. Further, there were no significant differences $(\mathrm{p}<0.05)$ in soil $\mathrm{pH}$ as well as in bioaccumulation of heavy metals in both the artificial and natural stands of $C$. procera. However, Pearson correlation analysis showed a very strong relationship (Pearson, $\mathrm{P}<0.01$, $\left.r_{s}=0.966\right)$ in terms of pytoextraction/phytoaccumulation of heavy metals ( $\mathrm{Zn}, \mathrm{Mn}, \mathrm{Cu}$ and Fe) between the artificial and natural stands of $C$. procera. The study concluded that $C$. procera can grow in a wide range of soil $\mathrm{pH}$ levels and the species has the ability to bioaccumulate heavy metals in its leafy tissues. The study recommends use of $C$. procera as a remediator of soils contaminated with heavy metals ( $\mathrm{Zn}, \mathrm{Mn}, \mathrm{Cu}$ and $\mathrm{Fe}$ ). 


\section{Introduction}

Calotropis procera (Aiton) W.T (Asclepiadaceae) is a xerophytic perennial shrub or small tree that grows in many arid and semi-arid countries (Hassan et al., 2015). According to Farahat et al., (2015), the species is a perennial xerophytic medicinal shrub or small tree that grows as a wasteland plant and reproduces by seeds. Frosi et al., (2013) describes the species as a perennial Asian shrub that primarily reproduces via seeds. According to Galal et al., (2015), the species is hardy xerophytic plant which is distributed globally in many countries and has important economic and ecological functions. The species is found in most parts of the world with a warm climate in dry, sandy and alkaline soils. It can tolerate adverse climatic conditions and poor soils (Parsons \& Cuthbertson 1992; Lottermoser 2011; Kumar et al., 2013). It has an evergreen behavior under field conditions, from young plant to the reproductive stage (Frosi et al., 2012). It often grows in saline or slightly saline soils with low soil moisture, forming mono-specific stands (El-Midany, 2014). The species is drought-resistant and salt-tolerant xerophytic species, which is capable of surviving in a range of soil types including alkaline and saline soil, and prefers free-draining sandy soils. It grows in open habitats and is particularly common in overgrazed pastures and on poor soils, where there is a little competition from grasses (Kumar et al., 2013; Galal, 2015).

In India, it is found at up to $1000 \mathrm{~m}$ altitude (Parrotta, 2001) in a wide variety of soil types and will survive on alkaline and saline soils though prefers free-draining sandy soils. It is found at a range of altitudes from exposed coastal sites to medium elevations up to $1300 \mathrm{~m}$. According to Kumar et al., (2013) the species prefers disturbed sandy soils. It thrives on poor soils, particularly where overgrazing has removed competition from native grasses, and forms dense thickets which compete with native plant species and transform the appearance of savannah plant communities.

It has a preference for and is often dominant in areas of abandoned cultivation especially sandy soils in areas of low rainfall and is assumed to be an indicator of over-cultivation (Orwa et al., 2009). The species is also found along roadsides, watercourses, river flats and coastal dunes, and is often prevalent in disturbed areas. It is deep-rooted, and so rarely grows in shallow soils over unfractured rock. Soils of all textures and derived from most parent materials are tolerated. It quickly becomes established as a weed along degraded roadsides, lagoon edges and in overgrazed native pastures.

The species is native to India, Pakistan, Nepal, Afghanistan, Algeria, Iran, Iraq, Israel, Kenya, Kuwait, Niger, Nigeria, Oman, Saudi Arabia, United Arab Emirates, Vietnam, Yemen and Zimbabwe (Kumar, et al., 2013).

In Kenya, C. procera wildly grows in Kitui, Machakos, Makueni, Tharaka, Baringo, Kibwezi, Turkana, Wajir, Isiolo, Mandera among other arid and semi arid areas (ASALs). It is native to tropical and subtropical Africa and Asia and common in the Middle East (Parsons \& Cuthbertson 1992; Lottermose 2011) and in Latin America. According to Orwa et al., (2009) and Galal et al., (2015), it has a wide range of uses such as medicinal, bark and latex are used in brewing and to curdle milk. Young pods used for fodder, stems produce good charcoal, fibre from stem and white silky wool, latex or rubber for tannin or dyestuff, poison for arrows and spears, soil fertility, pollution control by monitoring sulphur dioxide emissions in the air, suitable indicator of exhausted soil and plays a critical role in removal of heavy metals from the soil. 
A study was undertaken to evaluate the soil physical and chemical properties for growth of $C$. procera in a typical farm setting as well as in a natural environment.

Its ability to phytoextract heavy metals from the soil and concentration of the same in its leafy tissues was evaluated.

\section{Materials and Methods}

\section{Study Site}

\section{Geography}

The study was carried out at South Eastern Kenya University (SEKU) situated in Kitui County, Kenya. The research site is located 15 Kilometers off Kwa Vonza Market, along the Kitui-Machakos main road, Kwa Vonza/Yatta ward, Lower Yatta, Kitui County. Geographically, the research plot lies at $01.31358^{\circ} \mathrm{S}, \quad 037.75546^{\circ} \mathrm{E}$ and $01.31422^{\circ} \mathrm{S}$, $037.75576^{\circ} \mathrm{E}$ at a general elevation of $1173 \mathrm{~m}$ a.s.l (Figure 1).

\section{Climate of the study site}

The climate of the study areas is semi-arid (Agroecological zone IV) with very erratic and unreliable rainfall. The rainfall pattern is bimodal with the short rainy season occurring between November and December and the long one between April and May. The short rains are more reliable than the long rains (Pauw et al., 2008).

The mean annual rainfall ranges between 500$1050 \mathrm{~mm}$ with 40 per cent reliability. The site experiences high average temperatures throughout the year, which range from $16^{\circ} \mathrm{C}$ to $34^{0} \mathrm{C}$ (Pauw et al., 2008). The hot months are between January and February and June and September characterized by mean minimum and maximum temperatures of $28^{0}$ $\mathrm{C}$ and $32^{\circ} \mathrm{C}$, respectively.

\section{Hydrology and Water Resources}

Few water sources exist in the research site. The major sources of water are Mikuyuni and Mwita Syano seasonal streams. Virtually all of the seasonal rivers in the research area drain into the Tana River drainage basin, Kenya's largest river that drains the Eastern flank of the Aberdares and the Southern slopes of Mount Kenya. The river flows in the research area are characterized by very low flows (base flows) in dry season and high flows during rainy seasons, April-May and NovemberDecember respectively. Most of the ephemeral streams generally become dry within one month after the rainy season (Borst and De Haas, 2006). The flows are usually fast and turbid due to high sediment concentration associated with soil erosion in the catchment area.

\section{Soils and Geology}

Soils are predominantly sandy to loamy sand texture, hence they are susceptible to erosion and are limited in their capacity to retain water and nutrients. The major soil type of the area is lixisols (red soils). Alluvial deposits (fluvisols) occur in isolated patches along rivers and on hill slopes. The soils are generally poorly drained and easily eroded by runoff (Borst and De Haas, 2006). Some patches of the research area are overlain by red well drained sandy loam soils which have quartz and feldspar grains and felsic gravel rock fragments. Soil depths (thickness) vary from between $1.2 \mathrm{~m}$ (upslope) to nearly $2.0 \mathrm{~m}$ at the down slope side of Mwitasyano stream. The soils reduce in thickness upslope where rock outcrops are found jutting above the surface of the soils. The study site has a similar geology composed of high grade regional metamorphic granitoid granulites which are composed of quartz and feldspars (over 90\%) and mafic hornblende and pyroxenes (about $10 \%$ or less). 


\section{Selection of the Study Site}

The study site was selected purposively based on the following criteria. First, C. procera grows in drylands and the study site represents typical arid and semi-arid conditions. Secondly, the study site had a farmland where $C$. procera could be planted as well as existing natural stand of $C$. procera.

\section{Selection of $\boldsymbol{C}$. Procera Provenances}

To capture the dry land conditions in the country, seeds were collected from three areas in Kenya: Baringo, Kibwezi and Tharaka Nithi.

\section{Field Experimental Design}

A natural stand of $C$. procera was identified and demarcated within the study site for evaluation of soil physical and chemical properties under natural conditions. For artificial conditions, a $60 \mathrm{~m}$ by $80 \mathrm{~m}$ plot was cleared and leveled. Within the main plot, 27 subplots were demarcated. The subplots were laid out in a randomized complete block design within the main plot. In each of the subplot, 12 planting pits ( $1 \mathrm{ft}$ by $1 \mathrm{ft}$ ) were dug but at different spacing. For each provenance, three spacing types were used: $1.5 \mathrm{~m}$ by $1.5 \mathrm{~m}$, $2 \mathrm{~m}$ by $2 \mathrm{~m}$ and $3 \mathrm{~m}$ by $3 \mathrm{~m}$. These were replicated three times to give a total of 9 treatments. The spacing between subplots was $4 \mathrm{~m}$. The seedlings were transplanted into the pits. The planted $C$. procera were maintained in the field and monitored for four seasons (2 years).

\section{Soil sampling and analysis}

Soil samples were taken in the natural stand of $C$. procera as well as from the artificial plot before it was prepared for planting. In the natural stand of $C$. procera, sampling was done according to Kimiti et al., (2016) whereby a $100 \mathrm{~m}$ by $100 \mathrm{~m}$ sampling plot was established. A diagonal transect was ran across the sampling plot. Three soil sampling points were identified and marked; one at the centre and two at the edges of the diagonal transect. At each point, three plants of $C$. procera were identified and from each plant, soil samples were collected by auguring at $30 \mathrm{~cm}$ deep and $1 \mathrm{~m}$ away from the plant base. The soil cores were pooled, mixed and subsamples were taken for laboratory analysis. In each of the 27 subplots, the zigzag sampling method was used to collect four soil samples which were pooled, mixed and subsamples were taken for laboratory analysis. Soil extracts were prepared to meet the requirements for the different parameters, 1:5 $(\mathrm{w} / \mathrm{v})$ soils $(\mathrm{g})$ : distilled water $(\mathrm{ml})$. This extract was used to determine $\mathrm{pH}$ values using a glass electrode $\mathrm{pH}$ meter (Model $9107 \mathrm{BN}$, ORION type) and electrical conductivity (EC) with (conductivity meter 60 Sensor Operating Instruction Corning). Carbonates and bicarbonates were determined by titration against $0.1 \mathrm{~N} \mathrm{HCl}$ using phenol phthalein and methyl orange as indicators. Total $\mathrm{N}$ was estimated using Micro-Kjeldahl method, while total P using a spectrophotometer (CECIL CE 1021) by applying Indo-Phenol blue and molybdenum blue methods, respectively. Sodium and potassium were determined using flame photometer. Zinc, copper, iron and manganese were determined using Atomic Absorption ectrophotometer (Shimadzu AA6200).

\section{Plant tissue sampling and analysis}

At the end of the fourth season when the plants were 2 years old, four plants in each subplot were tagged and plant tissue samples were collected by harvesting the leaves of the plants. For each subplot, the harvested leaves were thoroughly mixed to form a bulk sample. For each subplot, a 500g sample (wet weight) was measured using a digital weighing 
balance. The samples were taken to the laboratory for complete chemical properties analysis (nitrogen, phosphorus, potassium, organic carbon, zinc, copper, manganese and iron).

\section{Data analysis}

One-way ANOVA was applied to assess the significance of variations in the soil chemical properties ( $\mathrm{pH}$, total $\mathrm{N}, \mathrm{P}$ and $\mathrm{K})$, Plant tissue data (total N, P, K, OC, $\mathrm{Zn}, \mathrm{Cu}, \mathrm{Mn}$ and $\mathrm{Fe}$ ), $C$. procera provenances and spacing variables in relation to the artificial $C$. procera stand. A comparative soil chemical properties $(\mathrm{pH}$ (water), EC (ms/c), C(\%), $\mathrm{NH}^{3-} \mathrm{N}(\mathrm{ppm}), \mathrm{N}$ (\%), P (ppm), K (ppm), Mn (ppm), Zn (ppm), $\mathrm{Fe}(\mathrm{ppm})$ and $\mathrm{Cu}(\mathrm{ppm})$ between the artificial and the natural stand of $C$. procera was done. Pearson simple linear correlation coefficient (r) was calculated to assess the type of relationship between the artificial and the natural stand of $C$. procera. Bioaccumulation levels of heavy metals ( $\mathrm{Zn}, \mathrm{Cu}, \mathrm{Mn}$ and $\mathrm{Fe}$ ) in the plant tissues of $C$. procera was determined and compared with the benchmark concentrations required for plant growth. Toxicity levels of the heavy metals were determined. Duncan Multiple Range Test (DMRT) was done to detect existence of statistically significant differences in bioaccumulation of heavy metals in the artificial and natural stands of C. procera.

\section{Results and Discussion}

Soil properties at the trial plot and the natural stand of $C$. procera

The chemical properties of soil samples from the study site and the natural stand of $C$. procera were analyzed. The $\mathrm{pH}$ averaged at 6.3 in the $C$. procera field trial plot. When $\mathrm{pH}$ data for subplots was separated by both space and provenance and subjected to Duncan Multiple Range Test (DMTR), no statistically significant differences $(\mathrm{P}<0.05)$ were captured (Table 3.1). Similarly, no significant differences were obtained when the data was separated by space (Table 3.2). Analysis of soil $\mathrm{pH}$ in the naturally growing stand of $C$. procera gave an average of 6.23 , which was slightly below the field trial plot average. Other soil chemical properties analyzed included soil total $\mathrm{N}(\%)$, total $\mathrm{P}(\mathrm{ppm})$ and total K (ppm).

A comparative soil chemical properties $(\mathrm{pH}$ (water), EC (ms/c), C (\%), $\mathrm{NH}^{3-} \mathrm{N}(\mathrm{ppm}), \mathrm{N}$ (\%),P (ppm), K (ppm), Mn (ppm), Zn (ppm), $\mathrm{Fe}(\mathrm{ppm})$ and $\mathrm{Cu}(\mathrm{ppm})$ between the study site and the natural stand of $C$. procera was done. The comparative soil chemical properties (rhizosphere) only captured significant differences $(\mathrm{P}<0.05)$ for $\mathrm{K}$ and $\mathrm{Fe}$ with the study site capturing relatively higher concentrations of the two nutrients compared to the $C$. procera natural stand. A comparative analysis of soil physical properties (rhizosphere) between the study site and the $C$. procera natural stand showed higher moisture content (2.03) in the natural stand compared to 1.58 in the study site. The two sites recorded almost similar bulk densities $\left(\mathrm{g} / \mathrm{cm}^{3}\right)$ with the natural stand recording a mean of 1.08 compared to 1.1 for the study site. Correlation analysis showed a strong positive spatial relationship (Pearson, $\mathrm{P}<0.01, \mathrm{r}_{\mathrm{s}}=0.734$ ) in soil chemical properties between the study site and the natural stand of $C$. procera.

Analysis of $C$. procera leafy tissues showed a tendency by $C$. procera to bioaccumulate heavy metals mainly micronutrients such as $\mathrm{Zn}$, Mn and Fe. Pearson correlation analysis showed a very strong relationship (Pearson, $\left.\mathrm{P}<0.01, \quad \mathrm{r}_{\mathrm{s}}=0.966\right)$ in terms of pytoextraction/phytoaccumulation of heavy metals ( $\mathrm{Zn}, \mathrm{Mn}, \mathrm{Cu}$ and $\mathrm{Fe}$ ) between the artificial and natural stands of $C$. procera. For instance, mean bioaccumulation of $\mathrm{Zn}$ was 216.04 (ppm) which was slightly higher than 
the recommended concentrations (Table 3.3). $\mathrm{Mn}$ had a mean bioaccumulation of 151.62 (ppm) and 119.29 (ppm) in the artificial stand and in the natural stand respectively. Fe had a mean bioaccumulation of 502.86(ppm) which was within the toxic levels for plants. However, $\mathrm{Cu}$ had mean concentrations of 2.25 (ppm) which was within the safe levels for plant concentrations.

Lack of significant differences in soil chemical properties across the study site subplots is a clear indication that the microsites were homogenous and that the observed differences in performance of $C$. procera provenances cannot be attributed to the soil properties. With respect to $\mathrm{pH}$, the study can authoritatively ascertain that the study site had a $\mathrm{pH}$ commonly found in natural habitats of $C$. procera. Comparison of soil $\mathrm{pH}$ in the study site and that of the natural stand of $C$. procera showed that the soils were slightly acidic $(\mathrm{pH}$ of 6.3 in the study site and 6.23 in the natural stand). The findings of this study are in agreement with Frosi et al., (2012) who in a study of ecophysiological performance of $C$. procera in Brazil recorded a $\mathrm{pH}$ of 6.4 in a naturally growing stand of $C$. procera. Other studies have shown that $C$. procera can do well in soils that are acidic, neutral and basic. This implies that the species has a wide $\mathrm{pH}$ range and generally, the level of $\mathrm{pH}$ may not have played a critical role in determining the observed growth performance of the three provenances of $C$. procera in the current study.

Survival of the species in a wide range of $\mathrm{pH}$ levels has also been demonstrated in different studies. For instance, Galal et al., (2015), in a study of $C$. procera growing in different habitats, noted that the residential habitat had a $\mathrm{pH}$ of 7.7 while the roadside habitat had 7.8. Similarly, Farahat et al., (2015) analyzed soil $\mathrm{pH}$ in three $C$. procera growing habitats: residential areas, roadside and railway areas.
The result showed good growth in railway habitats which are not only characterized by high soil $\mathrm{pH}$ (8.3) but also higher concentrations of heavy metals such as $\mathrm{Zn}$, $\mathrm{Cu}, \mathrm{Pb}, \mathrm{Cd}$, and $\mathrm{Mn}$. Further, Oliveira et al., (2009) documented that the species can grow in soils that are shallow, acidic, infertile as well as soils with toxic levels of aluminium and heavy metals.

The more or less homogenous soil bulk densities in the study site and in the $C$. procera natural stand can be attributed to the location of the two sites. The natural stand is located at the outskirts of an urban area hence subject to occasional anthropogenic disturbances while the current study site had been previously subjected to slash and burn agriculture. Based on these anthropogenic disturbances, the sites can be categorized as relatively disturbed hence more or less homogenous in terms of soil bulk densities.

C. procera is not selective in nutrients requirement and as such the insignificant differences in soil macronutrients in different sub-plots at the study site may not have influenced growth of the provenances. Generally, $C$. procera is well adapted to survive in a wide range of soil types ranging from poorly drained black cotton soils to welldrained but infertile sandy soils. The adaptive capacity of the species to a wide range of soil types was demonstrated by De Oliveira et al., (2009) who, in a study in Brazil, found out that the species performed well in ironstonerich areas in Canga and seasonally dry forest in Caatinga. C. procera survives in soils of all textures as well as soils with high concentration of sodium. According to Kumar et al., (2013), C. procera has a relatively high degree of tolerance to salinity, prefers sandy soils and is capable of surviving in degraded areas. Adaptation to a wide range of edaphic factors by $C$. procera is further documented by Ara et al., (2017) who found out that the 
species can tolerate poor soils with limited fertility and moisture level.

According to Francis (2002) and Orwa et al., (2009), C. procera is drought and salt tolerant surviving in different types of soils as well as alkaline and saline soils. Similar tolerance to soil salinity is documented by Galal et al., (2015). Similarly, El-Midany (2014) found out that $C$. procera is drought and salt tolerant surviving in a wide range of soils and prefers free draining sandy soils. Elsewhere, Lottermoser (2011), in a study on colonization of abandoned mines by $C$. procera, noted that the species can tolerate adverse climatic conditions, poor and polluted soils. According to Kumar et al., (2013), one of the key features of $C$. procera is its ability to survive in different soil types.

The observed high concentration of heavy metals ( $\mathrm{ZN}, \mathrm{Cu}, \mathrm{Mn}$ and $\mathrm{Fe}$ ) in plant tissues of $C$. procera in the domestication site and the natural stand is an indicator of the species' ability to undertake phytoremediation. Pyhtoextraction/pytoremediation is the ability of plant species to remove contaminants such as heavy metals from the soil and air and accumulate them in their tissues such as the leaves, stems and roots. This aids in the removal of pollutants in the environment. Several studies have demonstrated the ability of $C$. procera to bioaccumulate heavy metals as observed in this study. For instance, Alyemeni et al., (2011), detected higher mean $\mathrm{Cd}$ and $\mathrm{Cu}$ values in above ground tissues of $C$. procera though the level were below the phytotoxic ranges of 5-700 $\mathrm{mg} \mathrm{kg-1}$ and 25$40 \mathrm{mg} \mathrm{kg}-1$ for $\mathrm{Cd}$ and $\mathrm{Cu}$ respectively. D'Souza et al., (2010), in a study of soil contaminated with $\mathrm{Pb}$ and $\mathrm{Cd}$ in India, identified $C$. procera as an effective phytoremediator of soils contaminated with heavy metals. In this study, though $C$. procera accumulated copper within its foliage, the concentrations (2.25) were within safe levels for plant growth. However, Galal et al., (2015) obtained mean concentration values of $\mathrm{Cu}$ of $24.2 \mathrm{mg} \mathrm{kg}-1$ in $C$. procera growing in railways habitat and the levels were considered to be within the toxic concentrations. It is important to note that though $\mathrm{Cu}$ is a heavy metal, it is vital a vital plant nutrient and plays a critical role in various enzymatic activities. Further, $\mathrm{Cu}$ tends to bio-accumulate in roots and is rarely concentrated into aboveground plant tissues such as the leaves and stems. Copper can cause toxicity when aboveground tissues pytoaccumulate levels beyond $20 \mathrm{mg} \mathrm{kg}-1$ (Galal et al., 2015). Plants affected by heavy metal toxicities show a wide range of leaf symptoms. For instance, $\mathrm{Cu}$ toxicity often causes foliar interveinal chlorosis with increasing exposure (Reichman, 2002).

This current study noted $\mathrm{Zn}$ bioaccumulation mean values of $216.04 \mathrm{mg} \mathrm{kg}-1$ that were almost reaching toxic levels. According to Ghaderian and Ravandi (2012), $\mathrm{Zn}$ is a vital nutrient for plants and occurs in concentrations of between 10-200 mg kg-1 with toxic concentrations starting from 230 $\mathrm{mg} \mathrm{kg}-1$. Zinc toxicity is manifested by symptoms such as chlorosis and reddening of younger leaves (Reichman, 2002). In a different study, Galal et al., (2015) obtained mean values of $\mathrm{Zn}$ pytoremediation of 58.5 $\mathrm{mg} \mathrm{kg}-1$ and $122.4 \mathrm{mg} \mathrm{kg}-1$ in $C$. procera growing in railway and roadside habitats respectively. In a different study using Sorghum bicolor, Mirshekali et al., (2012) reported that the plants tolerated $<900 \mathrm{mg} \mathrm{kg}$ 1 of zinc concentrations and as such recommended the plant as a phyto-remediator of zinc contaminated soils. 
Table.1 Means separation by both space and provenance

\begin{tabular}{|c|c|c|c|c|c|}
\hline \multicolumn{2}{|c|}{ pH water } & \multicolumn{3}{c|}{ Total P ppm } \\
\hline Baringo & 6.54 & $\mathrm{a}$ & 2 Baringo & 716.3 & $\mathrm{a}$ \\
\hline 3 Tharaka & 6.44 & $\mathrm{ab}$ & 3 Baringo & 658.8 & $\mathrm{a}$ \\
\hline 1.5 Kibwezi & 6.41 & $\mathrm{ab}$ & 1.5 Tharaka & 596 & $\mathrm{a}$ \\
\hline 1.5 Baringo & 6.41 & $\mathrm{ab}$ & 3 Kibwezi & 563.9 & $\mathrm{a}$ \\
\hline 3 Kibwezi & 6.39 & $\mathrm{ab}$ & 1.5 Baringo & 558.6 & $\mathrm{a}$ \\
\hline 2 Baringo & 6.38 & $\mathrm{ab}$ & 2 Kibwezi & 498.4 & $\mathrm{a}$ \\
\hline 1.5 Tharaka & 6.34 & $\mathrm{ab}$ & 3 Tharaka & 455.7 & $\mathrm{a}$ \\
\hline 2 Kibwezi & 6.21 & $\mathrm{ab}$ & 2 Tharaka & 427.6 & $\mathrm{a}$ \\
\hline 2 Tharaka & 6.18 & $\mathrm{~b}$ & 1.5 Kibwezi & 422.3 & $\mathrm{a}$ \\
\hline $\boldsymbol{p}$ value & $\mathbf{0 . 5 4 2}$ & & $\boldsymbol{p}$ value & $\mathbf{0 . 6 8}$ & \\
\hline
\end{tabular}

Table.1 Continued.....

\begin{tabular}{|c|c|c|c|c|c|}
\hline \multicolumn{4}{|c|}{ Total N\% } & \multicolumn{2}{c|}{ Total K ppm } \\
\hline 2 Baringo & 0.2667 & $\mathrm{a}$ & 1.5 Baringo & 1624 & $\mathrm{a}$ \\
\hline 3 Kibwezi & 0.2267 & $\mathrm{ab}$ & 3 Tharaka & 1547 & $\mathrm{ab}$ \\
\hline 3 Baringo & 0.2033 & $\mathrm{ab}$ & 2 Baringo & 1508 & $\mathrm{ab}$ \\
\hline 1.5 Kibwezi & 0.1867 & $\mathrm{ab}$ & 1.5 Kibwezi & 1466 & $\mathrm{ab}$ \\
\hline 2 Tharaka & 0.1867 & $\mathrm{ab}$ & 1.5 Tharaka & 1446 & $\mathrm{ab}$ \\
\hline 2 Kibwezi & 0.1867 & $\mathrm{ab}$ & 3 Kibwezi & 1444 & $\mathrm{ab}$ \\
\hline 3 Tharaka & 0.1667 & $\mathrm{ab}$ & 3 Baringo & 1437 & $\mathrm{ab}$ \\
\hline 1.5 Tharaka & 0.1633 & $\mathrm{ab}$ & 2 Tharaka & 1426 & $\mathrm{ab}$ \\
\hline 1.5 Baringo & 0.1433 & $\mathrm{~b}$ & 2 Kibwezi & 1181 & $\mathrm{~b}$ \\
\hline p value & $\mathbf{0 . 4 2 6}$ & & $\boldsymbol{p}$ value & $\mathbf{0 . 6 4 6}$ & \\
\hline
\end{tabular}

*Means bearing the same letter in a column are not significantly different

Table.2 Means separation by space

\begin{tabular}{|c|c|c|c|c|c|c|c|c|c|c|c|}
\hline 1_5Total_K_ppm & \multicolumn{3}{|c}{ 1_5Total_N\% } & \multicolumn{3}{c|}{ 1_5Total_p_ppm } & \multicolumn{2}{c|}{ 1_5pH_water } \\
\hline Baringo & 1624 & a & Kibwezi & 0.1867 & a & Tharaka & 596 & a & Kibwezi & 6.413 & a \\
\hline Kibwezi & 1466 & a & Tharaka & 0.1633 & a & Baringo & 558.6 & a & Baringo & 6.407 & a \\
\hline Tharaka & 1446 & a & Baringo & 0.1433 & a & Kibwezi & 422.3 & a & Tharaka & 6.34 & a \\
\hline $\boldsymbol{p}$ value & $\mathbf{0 . 2 3 2}$ & & p value & $\mathbf{0 . 5 2 6}$ & & p value & $\mathbf{0 . 7 2 3}$ & & p value & $\mathbf{0 . 8 9 6}$ \\
\hline
\end{tabular}

Table. 2 Continued.....

\begin{tabular}{|l|l|l|l|l|l|l|l|l|l|l|l|}
\hline \multicolumn{2}{|c|}{ 2 Total_K_ppm } & \multicolumn{3}{c|}{ 2 Total_N\% } & \multicolumn{2}{c|}{ 2 Total_p_ppm } & \multicolumn{2}{c|}{ 2 pH (water) } \\
\hline Baringo & 1508 & a & Baringo & 0.2667 & a & Baringo & 716.3 & a & Baringo & 6.383 & a \\
\hline Tharaka & 1426 & a & Kibwezi & 0.1867 & a & Kibwezi & 498.4 & a & Kibwezi & 6.213 & a \\
\hline Kibwezi & 1181 & a & Tharaka & 0.1867 & a & Tharaka & 427.6 & a & Tharaka & 6.18 & a \\
\hline p value & $\mathbf{0 . 4 8 8}$ & & p value & $\mathbf{0 . 3 9 4}$ & & p value & $\mathbf{0 . 2 1 2}$ & & p value & $\mathbf{0 . 2 1 4}$ & \\
\hline
\end{tabular}


Table.2 Continued.....

\begin{tabular}{|l|l|l|l|l|l|l|l|l|l|l|l|}
\hline \multicolumn{3}{|c|}{ 3 Total_K_ppm } & \multicolumn{3}{c|}{ 3 Total_N\% } & \multicolumn{3}{c|}{ 3 Total_p_ppm } & \multicolumn{3}{c|}{ 3 pH_water } \\
\hline Tharaka & 1547 & a & Kibwezi & 0.2267 & a & Baringo & 658.8 & a & Baringo & 6.537 & a \\
\hline Kibwezi & 1444 & a & Baringo & 0.2033 & a & Kibwezi & 563.9 & a & Tharaka & 6.443 & a \\
\hline Baringo & 1437 & a & Tharaka & 0.1667 & a & Tharaka & 455.7 & a & Kibwezi & 6.39 & a \\
\hline p value & $\mathbf{0 . 8 0 7}$ & & p value & $\mathbf{0 . 5 0 4}$ & & p value & $\mathbf{0 . 3 7 9}$ & & p value & $\mathbf{0 . 7 7 6}$ \\
\hline
\end{tabular}

*Means bearing the same letter in a column are not significantly different

Table.3 Mean concentration of different heavy metals by $C$. procera

\begin{tabular}{|l|l|l|l|l|}
\hline & Mn (ppm) & Zn (ppm) & Fe (ppm) & Cu (ppm) \\
\hline Natural stand of $\boldsymbol{C}$. procera & 119.29 & 202.12 & 524.24 & 1.31 \\
\hline Artificial stand & 151.62 & 216.04 & 502.86 & 2.25 \\
\hline $\begin{array}{l}\text { Normal (safe) concentrations } \\
\text { for plants }\end{array}$ & $50-500$ & $10-200$ & $50-250$ & $<20$ \\
\hline
\end{tabular}

Fig.1 Location of research site in SEKU, Kitui County, Kenya
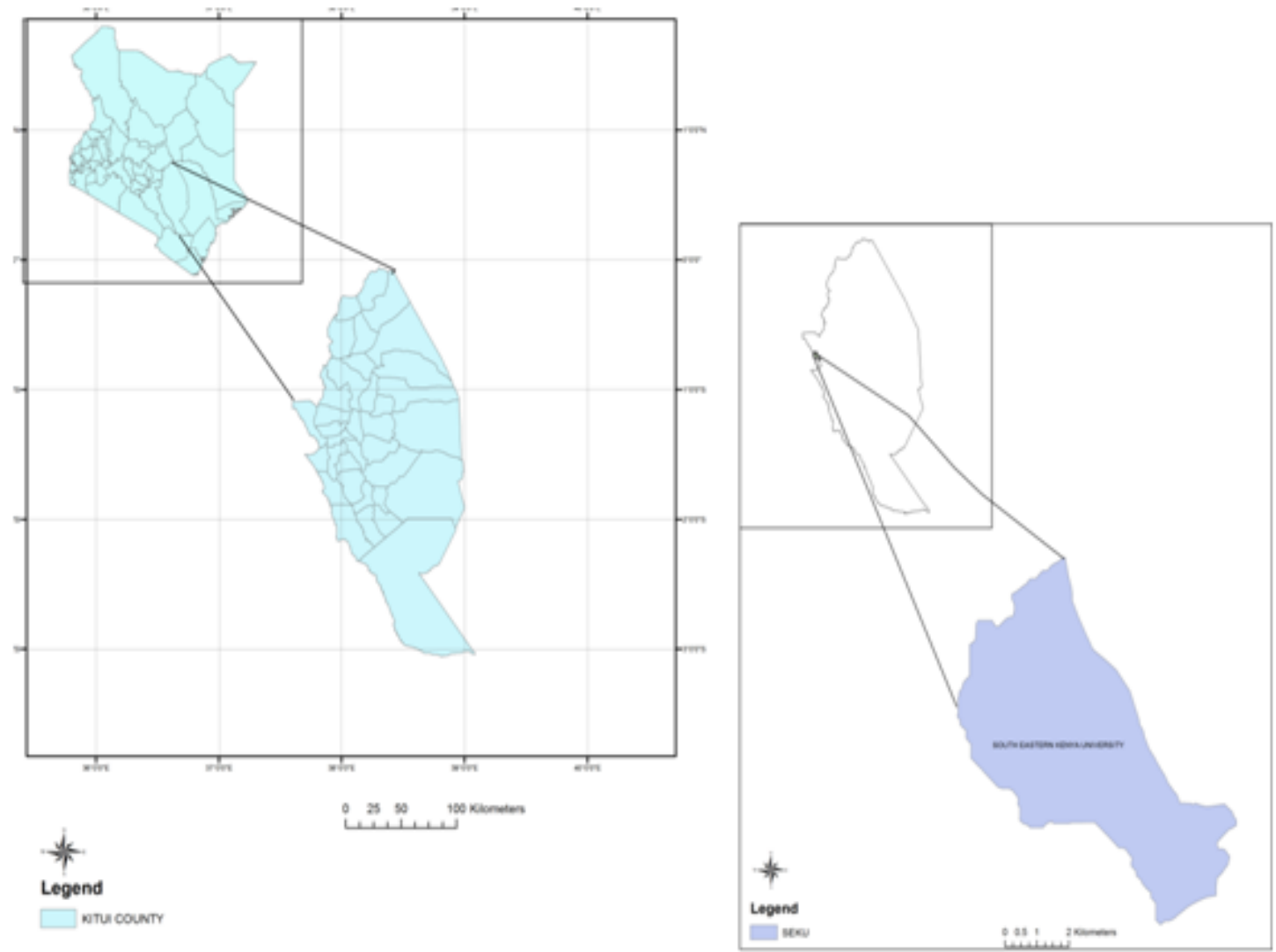

This study reported Mn bioaccumulation in leafy tissues of $C$. procera both in the artificial stand (151.62 mg kg-1) and the natural stand (119.29 mg kg-1). According to Galal et al.,
(2015), manganese plays a critical role in photosynthetic reaction and is important in a number of enzymes that catalyze redox, decarboxylation, and hydrolytic reactions. 
However, concentrations of Mn above 50-500 mg kg-1 are considered toxic to plants. As such, the mean concentration values obtained from the domestication site $(151.62 \mathrm{mg} \mathrm{kg}-1)$ and the natural stand of $C$. procera (119.29 $\mathrm{mg} \mathrm{kg-1)}$ were within the normal range for plant growth.

Toxicity symptoms of $\mathrm{Mn}$ include chlorosis especially on older leaves and necrotic lessions on young foliage (Reichman, 2002). Elsewhere, Prajapati et al., (2013) found out that $C$. procera is a phyto-remediator of soils contaminated with Mn owing to the species ability to bio-concentrate $\mathrm{Mn}$ in its above ground tissues. In a different study in Jeddah City-Kingdom of Saudi Arabia, Abdullatif et al., (2016)estimated the amount of heavy metals such as Aluminum, Chromium, Boron, Barium, Copper, Manganese, Iron, Lead and Zinc in the soil and plant tissues of $C$. procera. Results revealed that $C$. procera is capable of phytoextraction of the heavy metals and as such the species can be used as a phytoremediator by absorbing the pollutants from the soil as well as atmosphere and concentrating the same in the above ground tissues.

Out of the heavy metals analyzed, only Fe had bioaccumulation levels (502.86mg kg-1) that were within toxic concentrations for most plants. Similar accumulation of $\mathrm{Fe}$ to toxic concentrations were obtained by Galal et al., (2015) who reported that $\mathrm{Fe}$ concentration in $C$. procera from residential and roadside habitats exceeded the normal concentration for plant survival. Out of the micronutrients required by plants, $\mathrm{Fe}$ is needed in high amounts with normal concentration for plant growth ranging between $50-250 \mathrm{mg} \mathrm{kg}-1$. Iron is an essential micronutrient and plays critical role in DNA synthesis, enzymatically mediated processes, respiration and photosynthesis (Rout \& Sahoo, 2015).Fe toxicity symptoms include yellowing and dieback of oldest leaves, necrotic lessions, growth retardation among others. It is important to note that the growth of $C$. procera in the artificial stand and the natural stand was characterized by occasional leaf yellowing followed by complete defoliation and dieback of aerial shoots. Given the observed levels of $\mathrm{Fe}$ and the effects of its excess bioaccumulation, it is likely that it played a critical role in the observed occasional loss of chlorophyll, defoliation and dieback of shoots.

Comparing the $\mathrm{Fe}$ normal ranges of 50 and $250 \mathrm{mg} \mathrm{kg}-1$ and the mean values of $502.86 \mathrm{mg} \mathrm{kg}-1$ obtained in this study, it is evident that $C$. procera can tolerate exceptionally high Fe levels. This observation is further supported by De Oliveira1 et al., (2009) who, in a study in Canga and Caatinga in Brazil, found out that $C$. procera had the capacity to tolerate high levels of iron which is characteristic of Canga soils. In Riyadh and Gazan, Saudi Arabia, Al-Yemni et al., (2011) noted significant concentrations of nutrient and heavy metals such as $\mathrm{N}, \mathrm{Ca}, \mathrm{Cd}$ and $\mathrm{Fe}$ in above ground tissues of $\mathrm{C}$. procera and Citrullus colocynthis indicating that the two species have the potential for pollution monitoring of soils contaminated with such heavy metals. Elsewhere, in a study to monitor distribution of Nickel and Vanadium in Jeddah City, Saudi Arabia, Al-Dhaibani et al., (2018) noted concentrations of the two elements in the soil and $C$. procera tissues and recommended use of $C$. procera as a biological technique for monitoring the concentration of the two airbone heavy metals.

\section{Recommendations}

There were no significant differences in soil chemical properties in the field subplots and as such, chemical soil properties did not influence the observed growth and phenological characteristics in the three provenances of $C$. procera. 
C. procera prefers a slightly acidic soil and has the ability to concentrate heavy metals $(\mathrm{Zn}, \mathrm{Cu}, \mathrm{Mn}$ and $\mathrm{Fe}$ ) in the plant tissues indicating that the species has the ability to undertake phytoremediation/phytoextraction of soil contaminated with heavy metals.

The study recommends use of $C$. Procera as a heavy metal remediator especially in soils contaminated with $\mathrm{ZN}, \mathrm{Cu}, \mathrm{Mn}$ and Fe. There is need for further studies to establish if the observed periodic chlorosis followed by complete defoliation of $C$. procera stands is linked to bioaccumulation of heavy metals in the plant's leafy tissues. There is need for further research on the extent of bioaccumulation of heavy metals in other above-ground tissues of $C$. procera such as the stem.

\section{References}

Abdullatif, B., M. El-Kazan, and Al-Zahrani M. 2016.Phytoremediation Ability of Calotropis procera in Reducing Air Pollution in Jeddah City-Kingdom of Saudi Arabia. Int.J.Curr.Microbiol.App.Sci (2016) 5(3): 212-225

Al-Dhaibani, A., A. Ghazal andAlhagri I. 2018. Biomonitoring of Distribution of Nickel and Vanadium using Calotropis procera L. in Jeddah City, Saudi Arabia. J Pollut 2018, Vol 1(1):104

Al-Yemni, M., H. Sher, M. El-Sheikh and Eid E. 2011. Bioaccumulation of nutrient and heavy metals by Calotropis proceraand Citrullus colocynthis and their potential use as contamination indicators. Academic Journals, Scientific Research and Essays Vol.6 (4), pp. 966-976

Ara, M., S. Qiqa and Moustafa C. 2017. Population Ecology and Economic Importance of Calotropis procera as an Exotic Medicinal Plant. Journal of
Ecology \& Natural Resources. 1. 10.23880/JENR-16000105.

Borst, L., and Haas, A. 2006. Hydrology of sand storage dams. A case study in the Kiindu Catchment, Kitui District, Kenya, M.Sc. Thesis, Vrije Universiteit Amsterdam. 27p.

D'Souza, R., M. Varun, J. Masih and Paul M. 2010. Identification of Calotropis procera L.as apotential phytoaccumulator of heavy metals from contaminated soils in Urban North Central India. $J$ Hazard Mater.184(1-3):457-64.

El-Midany, M., 2014. Population dynamics of Calotropis procera (Aiton) W.T. Aiton inCairoProvince. M.SC. Thesis, Helwan University, Cairo.

Farahat, E., M. El-Midany and Hassan, L. 2015. Effect of urban habitat heterogeneity onfunctionaltraits plasticity of the invasive species Calotropis procera (Aiton) W. T. Aiton. Rend Fis Acc Lincei 26:193201

Francis, K., 2002. Calotropis procera (Ait.) Ait. In: Francis JK, ed. Wildland shrubs of the UnitedStates and its territories: thamnic descriptions. USDA Forest Service General Technical Report II TF-WB-1.

Galal, T., E. Farahat, M. El-Midany and Hassan L. 2015. Nutrients and heavy metals accumulation by the giant milkweed Calotropis procera (Aiton) W.T. Aiton inurbanized areas, Egypt. Rendiconti Lincei. Scienze Fisiche e Naturali. 27. 10.1007/s12210-0150468-4.

Ghaderian, S., and Ravandi, A. 2012. Accumulation of copper and other heavy metals by plants growing on Sarcheshmeh copper mining area. Iran J Geochem Expl 123:25-32

Hassan, L., T. Galal, E. Farahat and El-Miday M. 2015. "The biology of Calotropis 
procera(aiton)", W. T. Trees (2015) 29:311-320.

Kimiti, J., D. Odee J. Sutherland and Sprent, J. 2016. Natural rhizobial populations and nodulation status of woody legumes growing in diverse Kenyan conditions. Kluwer Academic Publishers, 1995-06.

Kumar, P., E. Suresh and Kalavathy, S. 2013. Review on a potential herb Calotropis gigantea (L.) R. Br. Sch. Acad. J. Pharm., 2013; 2(2): 135-143. Scholars Academic and Scientific Publisher.

Lottermoser, B., 2011. Colonization of the rehabilitated Mary Kathleen uranium mine site(Australia) by Calotropis procera: Toxicity risk to grazing animals. Journal of Geochemical Exploration Volume111, Issues 1-2, Pages 39-46

Mirshekali, H., H. Hadi, R. Amirnia and Khodaverdiloo H. 2012. Effect of zinc toxicity on plant productivity, chlorophyll and $\mathrm{Zn}$ contents of sorghum (Sorghum bicolor) and common lambsquarter (Chenopodium album. Int. J. Agric. Res. Rev. 2.

Oliveira, S., D. Negreiros and Fernandes, G. 2009. Seedling growth of the invader Calotropisprocera inironstone rupestrian field and seasonally dry forest soils. Neo Biol Conserv 4:69-76.

Orwa, C., A. Mutua, R. Kindt, R. Jamnadass and Anthony S. 2009. Agroforestree
Database: a tree reference and selection guide version 4.0. World Agroforestry Centre, Kenya.

Parsons, W. T., and Cuthbertson, E. G. 1992. Noxious Weeds of Australia. Melbourne, Australia: Inkata Press.

Parrotta, J. A., 2001. 'Healing plants of Peninsular India'. $C A B$ International, Wallingford, UK and New York. 944 p.

Pauw, W. P., S. Mutiso, G. Mutiso, H. K. Manzi, R. Lasage and Aerts, J. C. J. 2008. An Assessment of the Social and Economic Effects of the Kitui Sand Dams: Community based Adaptation to Climate Change.

Prajapati, S., and Meravi, N. 2013. Heavy metal speciation of soil and Calotropis procera from thermal power plant area. Proceedings of the International Academy of Ecology and Environmental Sciences, 2014, 4(2): 68-71.

Reichman, S., 2002. The Responses of Plants to Metal Toxicity: A Review Focusing on Copper, Manganese and Zinc. Australian Minerals \& Energy Environment Foundation. Paper No.14, ISBN 1-876205-13-X

Rout, G., and Sahoo, S. 2015. Role of Iron in Plant Growth and Metabolism. Reviews in Agricultural Science, 3: 124, 2015. Doi: 10.7831/Ras.3.1

\section{How to cite this article:}

Festus Mbatha Mutiso, Jacinta Kimiti, Alice Muchugi and Josphert Kimatu. 2021. Soil Ecology and Bioaccumulation of Heavy Metals by Calotropis procera (Ait) in Drylands of South Eastern Kenya. Int.J.Curr.Microbiol.App.Sci. 10(07): 545-556.

doi: https://doi.org/10.20546/ijcmas.2021.1007.060 